\title{
Effect of titania on fired characteristics of triaxial porcelain
}

\author{
SUNIPA BHATTACHARYYA ${ }^{\dagger}$, SWAPAN KUMAR DAS* and \\ NIRENDRA KRISHNA MITRA ${ }^{\dagger}$ \\ Clay and Traditional Ceramics Division, Central Glass and Ceramic Research Institute, Kolkata 700 032, India \\ ${ }^{\dagger}$ Department of Chemical Technology, Calcutta University, Kolkata 700 009, India
}

MS received 17 September 2004; revised 12 July 2005

\begin{abstract}
Titania was progressively added in the range 3-9 wt\% into a triaxial porcelain body consisting of clay, quartz and feldspar. The composed bodies were heated at five different temperatures in the range 1200$1400^{\circ} \mathrm{C}$ and their fired properties as well as phases evolved were studied. The results revealed that beyond $1300^{\circ} \mathrm{C}$, formation of more liquid phases caused bloating in samples which led to generation of pores. This effect is more pronounced in $\mathrm{TiO}_{2}$ containing samples. In the present system, $1300^{\circ} \mathrm{C}$ appeared to be the optimum temperature at which porosity was almost negligible and strength was maximum (45 MPa), particularly in presence of $\mathrm{TiO}_{2}$. From the results of XRD studies, it was revealed that quartz content primarily decreased with increase in $\mathrm{TiO}_{2}$ content due to excess glass formation and its subsequent dissolution. Mullite content increased with increase in $\mathrm{TiO}_{2}$ content. No significant effect was observed beyond 6 wt \% addition. Microstructure primarily showed the presence of quartz grain and cluster of smaller sized primary mullite crystals in both the samples without and with $\mathrm{TiO}_{2}$. Very few secondary mullite crystals were also observed. SEM picture of sample containing $9 \mathrm{wt} \% \mathrm{TiO}_{2}$ showed some grain boundary crack due to cooling stress generated in the glassy phase. The drastic reduction of residual strength after 8 cycles of heating at $800^{\circ} \mathrm{C}$ and cooling particularly in $\mathrm{TiO}_{2}$ containing samples suggests controlled heat treatment of the vitrified samples necessary to promote secondary crystallization process for the enhancement of strength. Attempts have also been made to correlate the constitutional parameters with the properties.
\end{abstract}

Keywords. Triaxial porcelain; titania; mineralizer; fired properties.

\section{Introduction}

The most significant development in the history of ceramics was the production of a vitrified, translucent porcelain body in china (Cox 1944). Although the term porcelain is sometimes applied to a variety of vitreous and near vitreous ware, it is more properly restricted to translucent vitreous ware. A wide range of triaxial ceramic compositions that are used in white ware industries basically contain clay, quartz and feldspar. The primary role of each of these raw materials in triaxial bodies are discussed earlier (Lundin 1959; Norton 1970; Carty and Senapati 1998). In these compositions, clay serves a dual purpose of providing fine particle size and good plasticity for forming. Feldspar acts as a flux, forming a viscous liquid at firing temperature and aids in vitrification. The quartz is mainly an inexpensive filler material which remains unreactive at low temperature of firing and forms a highly viscous liquid at higher temperatures. The main differences between the compositions are in relative amounts and kinds of feldspar and clay used. Mullite $\left(3 \mathrm{Al}_{2} \mathrm{O}_{3} \cdot 2 \mathrm{SiO}_{2}\right)$, $\alpha$-quartz and glass contribute major portion of porcelain

\footnotetext{
*Author for correspondence (swapan@cgcri.res.in)
}

microstructure in triaxial based clay-quartz-feldspar system (Lundin 1964). Lundin $(1959,1964)$ also indicated the formation of cristobalite phases when the rate of transition of quartz to cristobalite exceeds the rate of quartz dissolution. Schneider et al (1986) showed that the transformation of quartz to cristobalite can be accelerated by high crystal defect density and small particles. The potential for cristobalite formation however, becomes less likely. Several researchers (Comer 1960; Schuller 1964; Lundin 1964; Klug et al 1987, 1990) discussed the mechanism of mullite formation in porcelain bodies. Concentration gradient and diffusion rates of alkalis are the two important factors that affect mullite formation as reported by Lundin (1964). While Comer (1960) described the formation of mullite on the surface of clay relicts, Lundin (1964) proposed that this mullite in clay relicts serves as a seed for nucleation and crystallization in the feldspar relicts. As alkali diffuses out of feldspar at higher temperatures, secondary mullite in the form of needle shape nucleates and grows. Heating schedule has a crucial role to crystal morphology and structure of mullite within the glassy matrix of porcelain. Pask and Tomsia (1991) reported the formation of spinel structure at lower temperatures of slow heating which converts to orthorhombic mullite by reacting with silica. Fast heating rates lead to 
tetragonal mullite formation at temperatures as low as $980^{\circ} \mathrm{C}$ followed by orthorhombic mullite formation at higher temperatures.

Mineralogical compositions of porcelain bodies have been widely studied (Parmelle and Rodrignez 1942; Zografon 1968; Mackenzie 1969; Chaudhuri 1974; Johnson and Pask 1982; Maslennikova and Stoikova 2001) with special reference to the influence of some mineralizing agents on the development of the crystalline and glassy phases at higher temperatures. The mineralizers enter the glassy phase of the porcelain samples and modify the solubility of mullite in glass. Johnson and Pask (1982) reported that impurities such as $\mathrm{Fe}_{2} \mathrm{O}_{3}$ and $\mathrm{TiO}_{2}$ affect the kinetics and morphology of mullite formation and that the exsolution of silica facilitates mullite formation in kaolin. Chaudhuri (1974) observed maximum and minimum mullitization in the porcelain samples containing $2 \% \mathrm{Fe}_{2} \mathrm{O}_{3}$ and $4 \% \mathrm{ZnO}$, respectively. $\mathrm{ZnO}$ up to $1 \%$ and $2 \% \mathrm{TiO}_{2}$ promote development of mullite; whereas $\mathrm{Fe}_{2} \mathrm{O}_{3}$ continues to produce a higher yield of mullite in hard porcelain up to $4 \%$. More than $1 \% \mathrm{ZnO}$ makes the glass corrosive to mullite whereas up to $2 \% \mathrm{TiO}_{2}$ prevents attack of mullite by glass. Zografon (1968) reported that 1 to $3 \% \mathrm{TiO}_{2}$ could be tolerated in the glass without inhibiting mullitization. Porcelain is a semivitrified body consisting of both crystalline and glassy phases and the latter plays an important role controlling the major properties. In the present investigation the $\mathrm{TiO}_{2}$ content was varied between 3 and $9 \%$ with the intention to study its effect on primary mullite formation from dehydroxylated kaolinite and also to change the composition of the glassy phase leading to crystallization which may improve grain boundary condition. $\mathrm{Fe}_{2} \mathrm{O}_{3}$ was found to be the most efficient mineralizer at higher concentration level. The residual quartz and glass can react in presence of certain mineralizers by a two-step process i.e. replacement of $\mathrm{Al}^{3+}$ ion from glass by cation of the mineralizer and subsequent diffusion of $\mathrm{Al}^{3+}$ ion into the residual silica. The mineralizing action of a cation is dependent on the ease with which it can penerate into the proper structure. Radii and potential of the cation and the cation oxygen bond strength have been suggested to be the factors controlling penetrating power of the cation. Mackenzie (1969) studied the effect of 28 exchangeable cation on the formation of mullite from halloysite. He observed different kinds of reaction mechanism between alkaline and alkaline earth cation and transition metal cation.
In the present investigation, $\mathrm{TiO}_{2}$ was incorporated progressively into a parent triaxial porcelain composition and its effect on the physico-mechanical properties was studied. Qualitative estimation of quartz and mullite was done to indicate the influence of $\mathrm{TiO}_{2}$ on such composition using X-ray diffraction studies. Microstructural features of some selected samples were also examined through SEM of the polished and etched surface of the vitrified specimens.

\section{Experimental}

The major raw materials used in the study were collected from Indian source (China clay from Rajmahal, Bihar; Ball clay from Bikaner, Rajasthan; quartz and feldspar from Ranchi, Jharkand). For chemical analysis of these raw materials, gravimetric method was utilized to determine $\mathrm{SiO}_{2}$ and $\mathrm{Al}_{2} \mathrm{O}_{3}$ whereas $\mathrm{Fe}_{2} \mathrm{O}_{3}, \mathrm{CaO}$ and $\mathrm{MgO}$ were estimated volumetrically (Hillebrand and Lundell 1953). Alkalies were determined by flame photometry. Titania $\left(\mathrm{TiO}_{2}\right)$ was of pure chemical grade (BDH quality, E-Merck India Ltd.). One kilogram of each batch (A, B, C and D) were prepared according to the batch compositions presented in table 1 . All the batches were mixed separately and wet ground in a pot mill for $8 \mathrm{~h}$ to get the desired fineness (residue $<1.5 \mathrm{wt} \%$ on 200 mesh BS sieve). The slurry obtained was screened, dried at $110^{\circ} \mathrm{C}$ and powdered to break the agglomerate. A part of the powdered batches was calcined separately at $900^{\circ} \mathrm{C}$ with a soaking period of $2 \mathrm{~h}$ to remove all types of water from the mixture so that during firing undue shrinkage may be avoided. $85 \mathrm{wt} \%$ of the calcined batch was again thoroughly mixed with $15 \mathrm{wt} \%$ of uncalcined batch and $2 \%$ PVA solution as binder. Required amount of water was sprayed on the mixture and granulated to small particles for better compaction.

Samples $(60 \times 14 \times 5 \mathrm{~mm})$ were hydraulically compacted using uniaxial pressing at $350 \mathrm{~kg} \cdot \mathrm{cm}^{-2}$. The bar samples were dried at $110-120^{\circ} \mathrm{C}$ till the moisture content reduced to $<0.5 \%$. The dried samples were fired at five different temperatures $(1200,1250,1300,1350$, $1400^{\circ} \mathrm{C}$ ) for a soaking period of $120 \mathrm{~min}$ in an electrically operated laboratory furnace using a on/off control system. A constant heating rate of $10^{\circ} \mathrm{C} / \mathrm{min}$ up to $1000^{\circ} \mathrm{C}$ and $5^{\circ} \mathrm{C} / \mathrm{min}$ up to the peak temperature was maintained in each firing. Finally, the fired samples were subjected to physical tests such as linear shrinkage, ap-

Table 1. Batch compositions (wt \%).

\begin{tabular}{lccccc}
\hline Batch & China clay & Ball clay & Feldspar & Quartz & Titania \\
\hline A & 40 & 10 & 25 & 25 & Nil \\
B & 38.8 & $9 \cdot 7$ & $24 \cdot 25$ & $24 \cdot 25$ & 3 \\
C & 37.6 & 9.4 & 23.50 & 23.50 & 6 \\
D & $36 \cdot 4$ & $9 \cdot 1$ & 22.75 & 22.75 & 9 \\
\hline
\end{tabular}


parent porosity and bulk density. Bulk density (BD) and per cent apparent porosity (AP) of the fired samples were measured using conventional liquid displacement method according to Archimedes principle. Flexural strength (three-point bending) of the fired samples was determined by universal testing machine (INSTRON $5500 \mathrm{R}$ ). The results of all these testings reported here are the average of six samples. Philips 'X-pert Pro' diffraction unit, with secondary monochromator, automatic divergence slit and nickel filter ( $\mathrm{Cu}-\mathrm{K} \alpha$ radiation) was used to identify the various phases formed in vitrified samples. XRD studies were carried out with powder ( -200 mesh BS sieve). For SEM study, samples were polished to $1 \mu \mathrm{m}$ finish with diamond paste after initial grinding with $\mathrm{SiC}$ powder and water. The polished surface of each samples were etched for $3 \mathrm{~min}$ in $5 \% \mathrm{HF}$ solution at room temperature $\left(350^{\circ} \mathrm{C}\right)$, washed in water and acetone followed by gold sputter coating (Edwards, Scancoat). SEM (LEO $430 \mathrm{i}$ ) was used for obtaining secondary electron images.

\section{Results and discussion}

The results of chemical analysis of the raw materials are given in table 2 . The chemical analysis results indicate that china clay, ball clay, quartz and feldspar are of normal type generally used in porcelain body with minimum amount of impurities.

The results of linear shrinkage are graphically represented in figure 1. It may be noted from this figure that the temperature effect was not linear. Linear shrinkage increased with increase in firing temperature up to $1300^{\circ} \mathrm{C}$ followed by significant decreasing trend up to $1400^{\circ} \mathrm{C}$. This might be related to the formation of more liquid phase causing bloating (generation of pores leading to expansion). This trend was observed with all the compositions. It may also be observed that shrinkage increased with increase in $\mathrm{TiO}_{2}$ content. This may be explained in the way that $\mathrm{TiO}_{2}$ increased the rate of reaction. In presence of $\mathrm{TiO}_{2}$, shrinkage increased sig-

Table 2. Chemical analysis of raw materials.

\begin{tabular}{|c|c|c|c|c|c|}
\hline $\begin{array}{l}\text { Major chemical } \\
\text { constituents (wt } \% \text { ) }\end{array}$ & China clay & Ball clay & Quartz & Feldspar & Titania \\
\hline $\mathrm{SiO}_{2}$ & $45 \cdot 41$ & $59 \cdot 25$ & 98.66 & $66 \cdot 48$ & - \\
\hline $\mathrm{Al}_{2} \mathrm{O}_{3}$ & $34 \cdot 39$ & $30 \cdot 75$ & 0.39 & $17 \cdot 29$ & - \\
\hline $\mathrm{Fe}_{2} \mathrm{O}_{3}$ & $1 \cdot 13$ & $1 \cdot 23$ & 0.07 & $0 \cdot 14$ & $<0.07$ \\
\hline $\mathrm{TiO}_{2}$ & 0.89 & 0.52 & $0 \cdot 01$ & 0.02 & $98 \cdot 00$ \\
\hline $\mathrm{CaO}$ & 1.07 & $0 \cdot 34$ & $0 \cdot 10$ & $0 \cdot 31$ & - \\
\hline $\mathrm{MgO}$ & $0 \cdot 76$ & $0 \cdot 25$ & 0.02 & 0.03 & - \\
\hline $\mathrm{K}_{2} \mathrm{O}$ & 0.42 & $0 \cdot 82$ & $0 \cdot 12$ & 11.95 & - \\
\hline $\mathrm{Na}_{2} \mathrm{O}$ & 0.87 & $0 \cdot 27$ & 0.09 & 2.94 & - \\
\hline L.O.I. & 14.67 & $10 \cdot 50$ & $0 \cdot 37$ & 0.71 & 0.50 \\
\hline
\end{tabular}

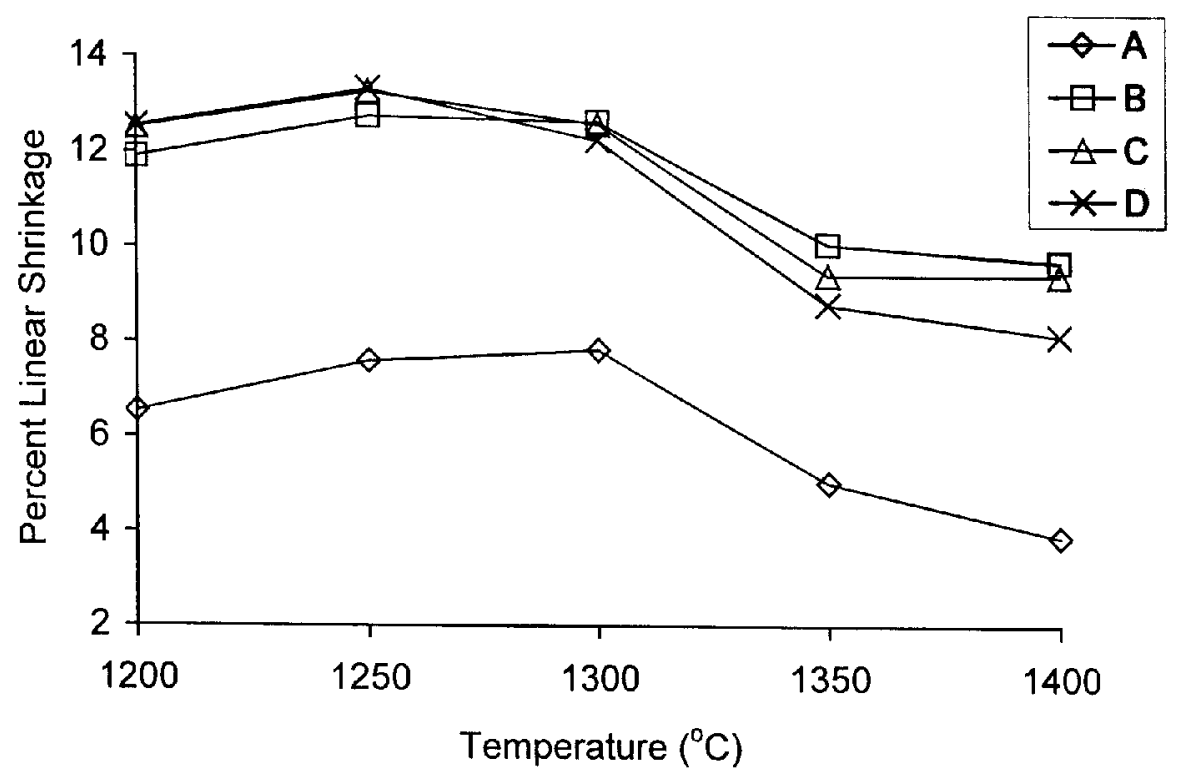

Figure 1. Variation of linear shrinkage with temperature of heating. 
nificantly which might be due to enhanced crystallization (mullitization) and formation of more flowable glassy phase. $\mathrm{TiO}_{2}$ containing samples exhibited similar nature of curves. Initial rate was slow compared to that without $\mathrm{TiO}_{2}$. Two inflection points were observed, first one at $1300^{\circ} \mathrm{C}$ which was very sharp with $\mathrm{TiO}_{2}$ containing samples. The second one at $1350^{\circ} \mathrm{C}$ where the slope was small. The shrinkage in this type of triaxial system was due to removal of residual amount of water from clay, decomposition of binder, liquid formation from the flux as well as generation of crystalline phases from amorphous materials. The results indicated that the pyrochemical reactions in this type of compositions did not attain equilibrium under the present experimental condi- tions. From the physical appearance of the fired samples, no distortion or sagging was observed. The formation of glass and simultaneous dissolution and subsequent reprecipitation of crystalline phases are the main controlling factors leading to shrinkage and expansion. The extent of primary reactions amongst the different ingredients was indicated by the first inflection point i.e. shrinkage maxima. The general trend of interaction remained more or less same at all compositions, only the magnitude differed. This type of interaction is a case of viscous composite sintering which involves much larger liquid contents than liquid phase sintering.

The results of apparent porosity are presented in figure 2. It is revealed from the figure that porosity decreased

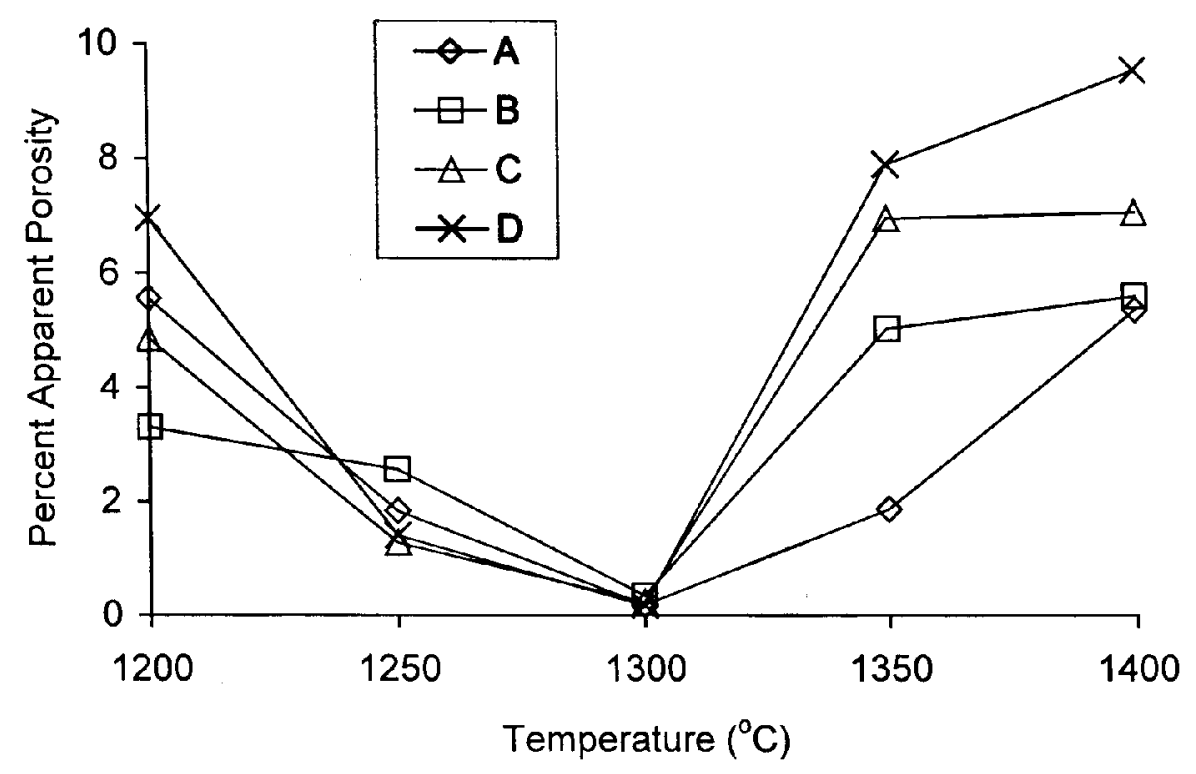

Figure 2. Variation of apparent porosity with temperature of heating.

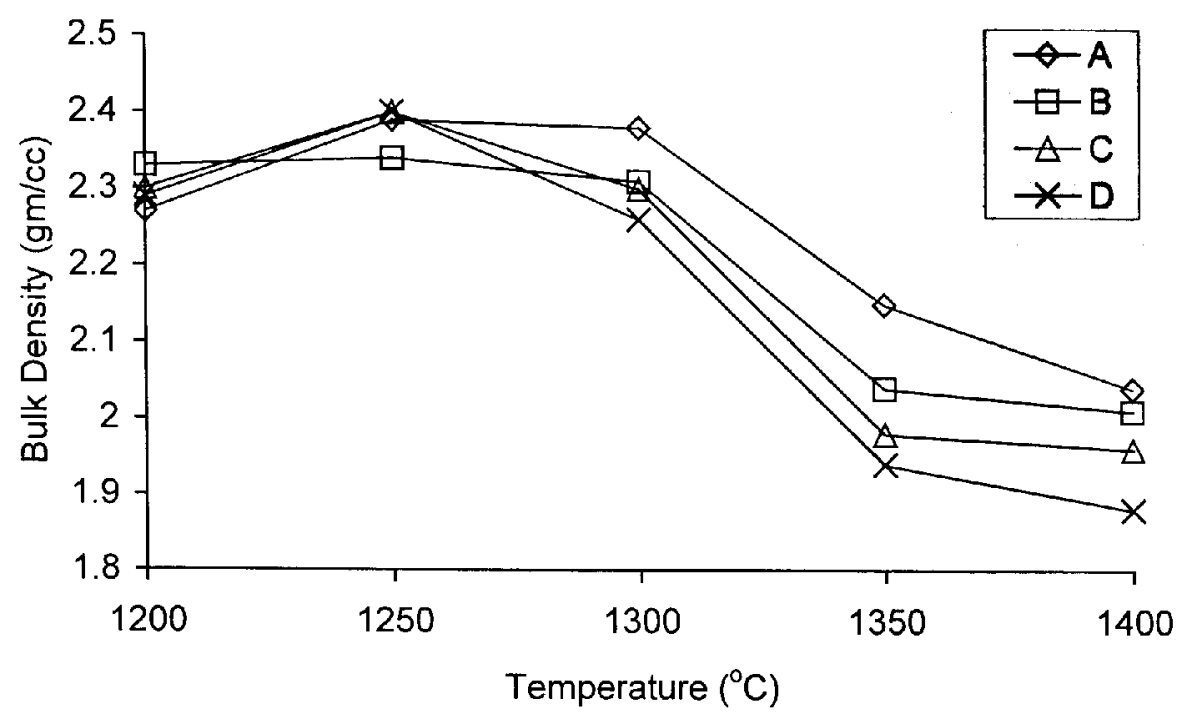

Figure 3. Variation of bulk density with temperature of heating. 
with increase in firing temperature due to material transport into the pores as well as migration of glassy phase therein also. This trend was followed up to $1300^{\circ} \mathrm{C}$ beyond which it increased again. The latter phenomenon was due to bloating action leading to pore formation in a vitrified mass. Minimum porosity was noticed at $1300^{\circ} \mathrm{C}$. Thus, it may be said that in this particular system, $1300^{\circ} \mathrm{C}$ appeared to be the optimum temperature at which apparent porosity was almost negligible particularly in presence of $\mathrm{TiO}_{2}$. The relationship between bulk density and firing temperature has been shown in figure 3 . The results show that the composition without $\mathrm{TiO}_{2}$ exhibited increase of bulk density up to $1300^{\circ} \mathrm{C}$ following which it decreased. Titania promoted the reaction that was evident from an increase of bulk density at earlier temperature $\left(1250^{\circ} \mathrm{C}\right)$. At higher temperature, the rate of change of bulk density was significantly high. Moreover, the curves were analogous to the corresponding shrinkage curves.

Variation of room temperature flexural strength with temperature is shown in figure 4 . From the figure it is revealed that this triaxial body either in presence or absence of $\mathrm{TiO}_{2}$ showed maximum strength at $1300^{\circ} \mathrm{C}$ following which it decreased. The latter phenomenon may be related to the formation of more glassy phase which probably effect the proper interlocking of mullite needles in the microstructure. At $1300^{\circ} \mathrm{C}$, flexural strength increased with increase in $\mathrm{TiO}_{2}$ and maximum strength achieved was $45 \mathrm{MPa}$. The nature of the curves was identical indicating that same mechanism was followed at all $\mathrm{TiO}_{2}$ contents. The increase of bending strength with $9 \%$ $\mathrm{TiO}_{2}$ was not significantly high compared to $6 \%$, only a marginal increase which might not be totally related to mullite formation but alignment of mullite crystals, their growth characteristics and nature of the glassy phase. With increasing $\mathrm{TiO}_{2}$ content there was a strengthening of the decomposition of mullite thereby increasing the amount of glass and aluminium titanate.
Substitution of $\mathrm{Al}^{+3}$ by $\mathrm{Ti}^{+4}$ probably in the octahedral sites of mullite crystals could cause aluminium ion vacancy according to following reflect reaction

$$
\begin{aligned}
& (1-X) \mathrm{Al}_{2} \mathrm{O}_{3}+X \mathrm{TiO}_{2} \longrightarrow 2(1-X) \\
& \mathrm{Al}_{\mathrm{Al}}+X \mathrm{Ti}_{\mathrm{Al}}+X / 3 V_{\mathrm{Al}}^{\mathrm{III}}+(3-X) \mathrm{O}_{\mathrm{O}},
\end{aligned}
$$

which enhances mass transport and consequently reaction rate. Lattice parameters and unit cell volume for solid solution series increased with increasing amount of foreign oxide. The $\mathrm{TiO}_{2}$ contributed defect formation during reaction. From $1300^{\circ} \mathrm{C}$, the rate of decrease of strength on increase of temperature was faster than the corresponding increase from the earlier temperature. Initially, $\mathrm{TiO}_{2}$ entered into mullite grain by solid solution formation without much change in composition or amount of viscous phase. At higher temperature, the lower strength value was due to change in composition of the glassy phase. Elastic bond relaxation at high temperature might be also a contributing factor.

The samples heated at $1300^{\circ} \mathrm{C}$ was subjected to thermal shock (repeated heating at $800^{\circ} \mathrm{C}$ and cooling) and the results of residual flexural strength after eighth cycles of alternate heating and cooling are given in table 3 . Drastic reduction of strength occurred and this was accelerated by the presence of $\mathrm{TiO}_{2}$. This might be related to the formation of low viscosity glass. This finding suggests that this type of body containing $\mathrm{TiO}_{2}$ as additive should be further heat treated to effect crystallization

Table 3. Residual flexural strength.

\begin{tabular}{lc}
\hline Batch & Flexural strength (MPa) \\
\hline A & 5.98 \\
B & 2.77 \\
C & 2.40 \\
D & 2.79 \\
\hline
\end{tabular}

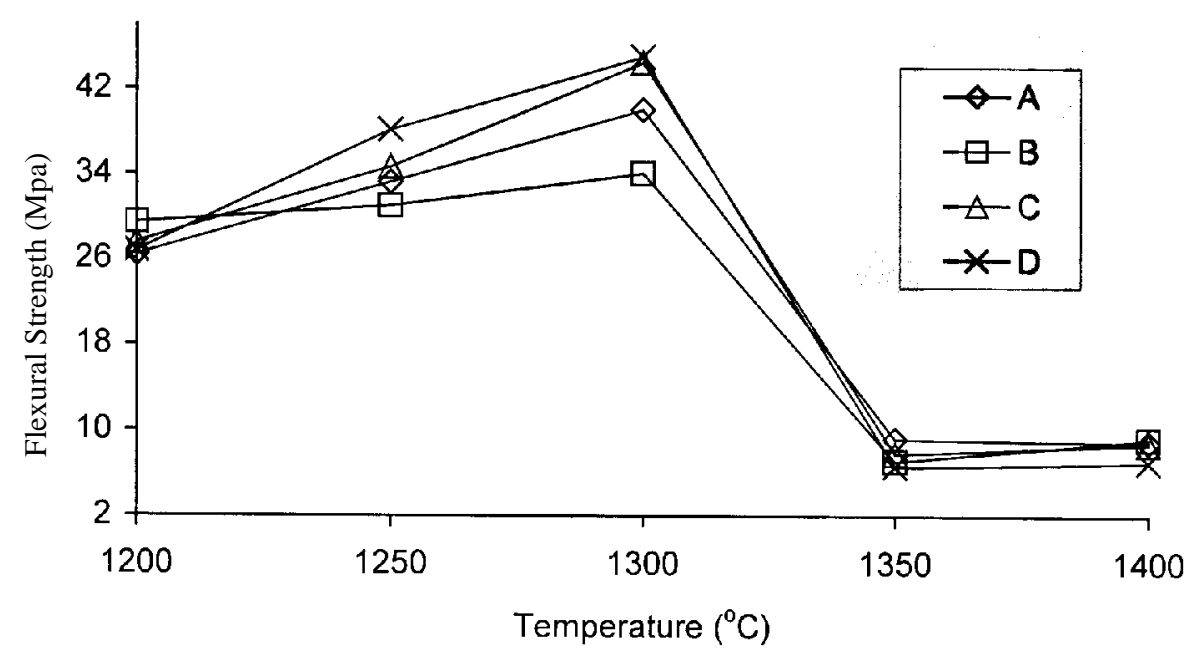

Figure 4. Variation of flexural strength with temperature of heating. 
from the glass phase for the enhancement of mechanical properties as well as thermal shock resistance.

The most important aspects related to thermal interaction among the ingredients and generation of newer crystalline phases were done by carrying out X-ray diffraction analysis. The diffraction pattern of $1300^{\circ} \mathrm{C}$ heated samples have been represented in figure 5. In all the patterns, quartz and mullite were found to be the major crystalline phases. From the peak heights, it was evident that quartz content primarily decreased with increase in $\mathrm{TiO}_{2}$ content which might be due to excess glass formation that caused some dissolution of quartz. It may also be observed that mullite content increased with increase in $\mathrm{TiO}_{2}$ content and no significant effect was observed beyond $6 \mathrm{wt} \%$ addition. The SEM photomicrographs taken on some selected polished and HF etched samples show the presence of quartz grain and cluster of smaller sized primary mullite crystals in both the samples (figures $6 a$ and b). Very few secondary mullite crystals are observed. The morphology of mullite grains is very much dependent on $\mathrm{TiO}_{2}$. At higher concentration it accelerated grain growth which was observed with batch $\mathrm{D}\left(9 \% \mathrm{TiO}_{2}\right.$ containing sample). This growth led to some grain boundary crack due to cooling stress generated in the glassy phase. This observation suggests that if $\mathrm{TiO}_{2}$ containing samples were subjected to further controlled heat treatment at lower temperature the secondary mullite could have developed by secondary crystallization process.

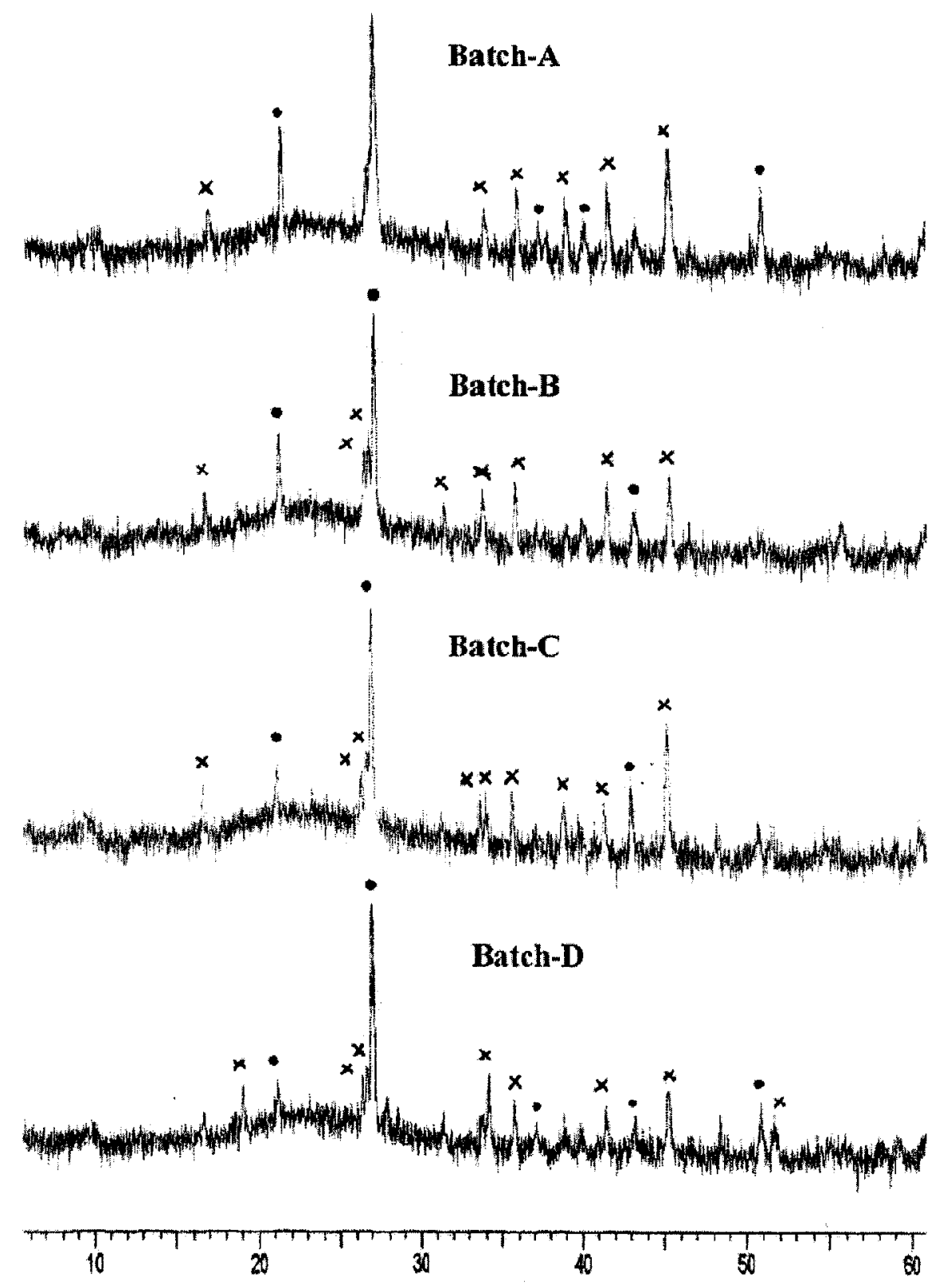

Figure 5. XRD pattern of different batches fired at $1300^{\circ} \mathrm{C}(\bullet$, quartz; $\times$, mullite $)$. 

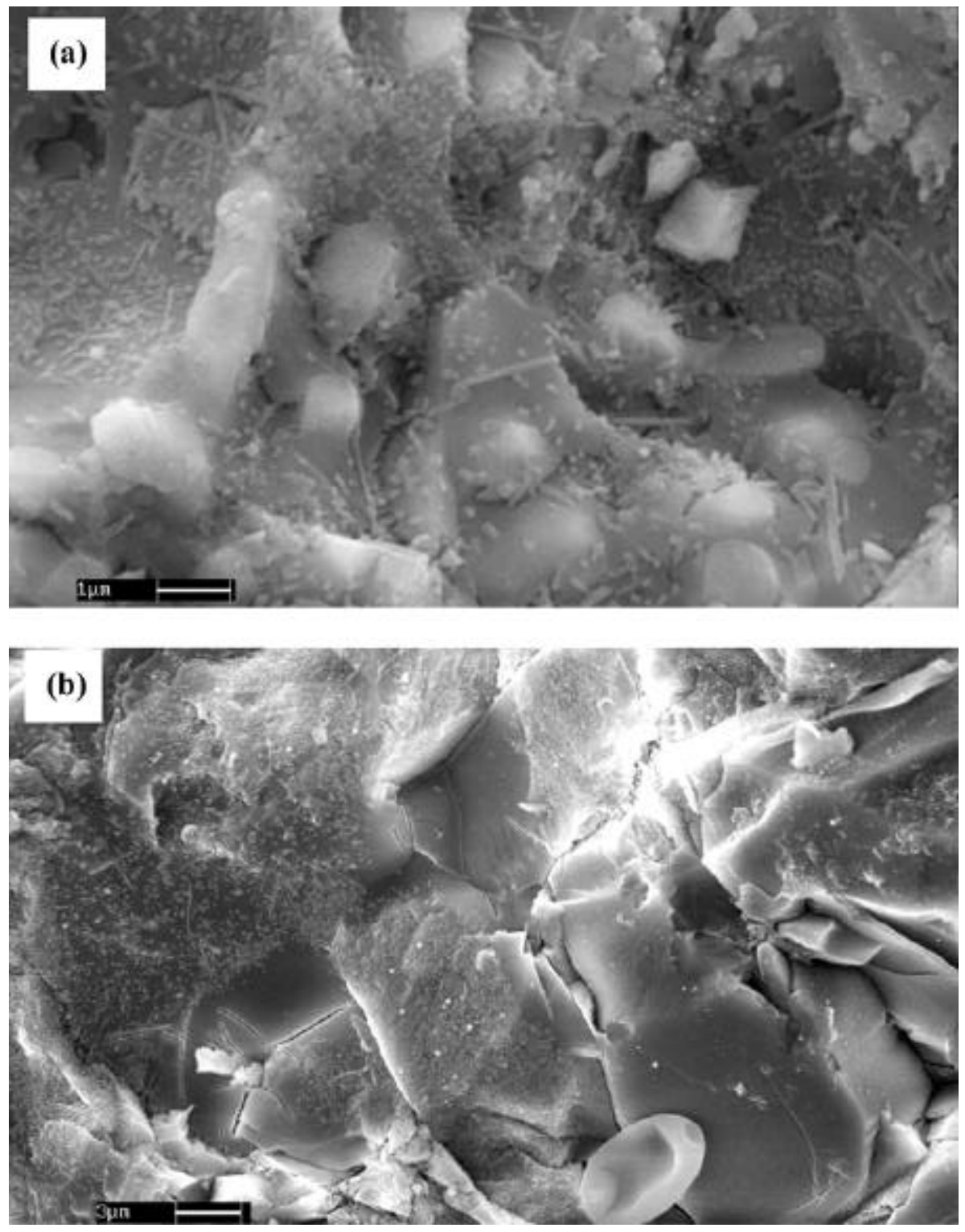

Figure 6. SEM photomicrographs of samples heated at $1300^{\circ} \mathrm{C}$ (polished and etched): (a) batch A and (b) batch D.

\section{Conclusions}

The standard triaxial porcelain body either in presence or absence of titania showed optimum physical properties and maximum strength at $1300^{\circ} \mathrm{C}$ following which the properties deteriorated. The effect is more pronounced in $\mathrm{TiO}_{2}$ containing samples due to excess formation of glassy phases. XRD results confirmed the presence of quartz and mullite as major phases. Quartz content decreased with increase of $\mathrm{TiO}_{2}$ content due to excess glass formation and its simultaneous dissolution while mullite content increased with $\mathrm{TiO}_{2}$ content. SEM photomicrograph show the presence of quartz grain and cluster of smaller sized primary mullite crystals with very few secondary mullite needles in both the cases. The drastic reduction of residual strength particularly in $\mathrm{TiO}_{2}$ containing samples after repeated heating and cooling suggests controlled heat treatment necessary in order to promote secondary recrystallization for the enhancement of strength and thermal shock resistance.

\section{Acknowledgements}

The authors would like to thank Dr S Ghatak and Shri S Chakrabarti, Central Glass and Ceramic Research Institute, Kolkata, for their encouragement and valuable suggestions provided during the course of investigation.

\section{References}

Carty W M and Senapati U 1998 J. Am. Ceram. Soc. 813 
Chaudhuri S P 1974 Ceram. Bull. 53169

Comer J J 1960 J. Am. Ceram. Soc. 43378

Cox W E 1944 The book of pottery and porcelain (New York: Crown) 2nd vol.

Hillebrand W F and Lundell G E F 1953 Applied inorganic analysis (New York: John Wiley \& Sons) 2nd ed.

Johnson S M and Pask J A 1982 J. Am. Ceram. Soc. Bull. 61838

Klug F J, Prochazka S and Doremns R H 1987 J. Am. Ceram. Soc. 70750

Klug F J, Prochazka S and Doremns R H 1990 Ceramic transaction, in Mullite and mullite matrix composition (eds) R F Davis et al (Westervile, OH: Am. Ceram. Soc.) 615

Lundin S T 1959 Studies on triaxial porcelain bodies (Stockholm, Sweden: Almgvist and Wiksell)
Lundin S T 1964 Microstructure of porcelain (USA: Nat. Bur. Stand. Misc. Publ.) 257 p. 93

Mackenzie K J D 1969 Trans. Br. Ceram. Soc. 6897

Maslennikova G N and Stoikova T V 2001 Kluwer journals 58 248

Norton F H 1970 Fine ceramics-Technology and applications (New York: McGraw Hill Book Co.)

Pask J A and Tomsia A P 1991 J. Am. Ceram. Soc. 742367

Parmelle C W and Rodrignez A R 1942 J. Am. Ceram. Soc. 25 1

Schneider H, Majdic A and Vasudevan R 1986 Mater. Sci. Forum 79

Schuller K H 1964 Trans. Br. Ceram. Soc. 63102

Zografon C 1968 Tomnd.-Zig. Keram. Rundschan 92478 